\title{
Hotspots for Nitrogen and Phosphorus Losses from Food Production in China: A County-Scale Analysis
}

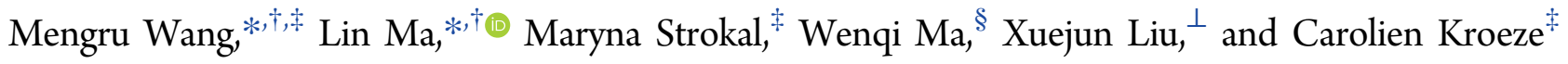

${ }^{\dagger}$ Key Laboratory of Agricultural Water Resources, Center for Agricultural Resources Research, Institute of Genetics and Developmental Biology, Chinese Academy of Sciences, 286 Huaizhong Road, Shijiazhuang 050021, China

${ }^{*}$ Water Systems and Global Change Group, Wageningen University and Research, Droevendaalsesteeg 4, Wageningen, 6708 PB, The Netherlands

${ }^{\S}$ College of Resources and Environmental Sciences, Agricultural University of Hebei, Baoding, 071001, China

${ }^{\perp}$ College of Resources and Environmental Sciences, China Agricultural University, Beijing 100193, China

Supporting Information

ABSTRACT: Food production in China results in large losses of nitrogen $(\mathrm{N})$ and phosphorus $(\mathrm{P})$ to the environment. Our objective is to identify hotspots for $\mathrm{N}$ and $\mathrm{P}$ losses to the environment from food production in China at the county scale. To do this, we used the NUFER (Nutrient flows in Food chains, Environment and Resources use) model. Between 1990 and 2012, the hotspot area expanded by a factor of 3 for N, and 24 for P. In 2012 most hotspots were found in the North China Plain. Hotspots covered less than $10 \%$ of the Chinese land area, but contributed by more than half to $\mathrm{N}$ and $\mathrm{P}$ losses to the environment. Direct discharge of animal manure to rivers was an important cause of $\mathrm{N}$ and $\mathrm{P}$ losses. Food production was found to be more intensive in hotspots than in other counties. Synthetic fertilizer use and animal numbers in hotspots were a factor of 4-5 higher than in other counties in 2012. Also the number of people working in food production and the incomes of farmers are higher in hotspots than in other counties. This study concludes with suggestions for region-specific pollution control technologies for food production in China.

\section{INTRODUCTION}

Nitrogen (N) and phosphorus (P) applications in food production greatly contribute to global food security as essential nutrients for the growth of plants and animals. However, this can also lead to $\mathrm{N}$ and $\mathrm{P}$ losses to the environment. ${ }^{1-6}$ Increasing losses of $\mathrm{N}$ and $\mathrm{P}$ to surface waters and the atmosphere have negative impacts on ecosystems and biodiversity. For example, increased $\mathrm{N}$ and $\mathrm{P}$ losses from food production may cause eutrophication and harmful algae blooms in many coastal areas around the world. ${ }^{7-11}$

$\mathrm{N}$ and $\mathrm{P}$ losses from food production including crop and animal production in China have been increasing since the 1980s. ${ }^{12-16} \mathrm{Ma}$ et al. ${ }^{17}$ estimated that total P losses from crop production in 2005 were $300 \%$ higher than that in 1980, while from animal production $\mathrm{P}$ losses were more than 42 times as high as that in 1980 in China. This implies that an increasing amount of nutrients was lost to air and waters. ${ }^{4,9,18-21}$ Various studies discussed the reasons why nutrient losses in China are high and increasing. ${ }^{4,9,19,21-25}$ An important reason is poor nutrient management technologies in food production: overuse of synthetic fertilizers and animal feeds, low productivity, and poor management of animal manure. However, most existing analyses are limited to the national or provincial levels, and they

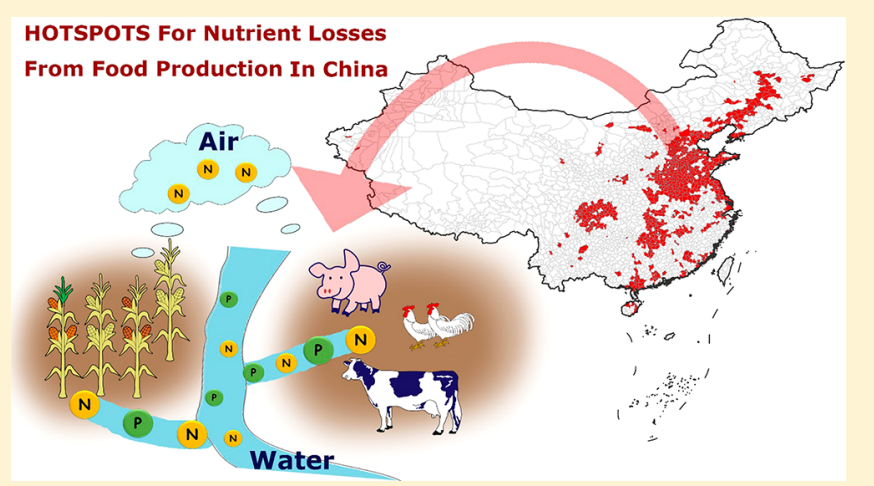

often do not discuss the possible relations between nutrient losses and socio-economic conditions that are usually the drivers of intensive food production in China. ${ }^{22,24-27} \mathrm{~A}$ more detailed analysis of $\mathrm{N}$ and $\mathrm{P}$ losses from food production at, for instance, the county scale does not exist. Such an analysis is highly relevant because it can provide more explicit quantitative information on $\mathrm{N}$ and $\mathrm{P}$ flows in food production in China. The result will contribute to identifying the "hotspots" where N and $\mathrm{P}$ losses from food production are higher than other regions. Analyzing the $\mathrm{N}$ and $\mathrm{P}$ flows in the hotspots and local agricultural and socio-economic indicators may help to develop region-specific nutrient management technologies and policies to reduce the potential for nutrient pollution in China.

Thus, our study aims to identify hotspots for $\mathrm{N}$ and $\mathrm{P}$ losses to the environment from food production in China at the county scale. To do this, we used the NUFER ${ }^{28}$ (Nutrient flows in Food chains, Environment, and Resources use) model. We analyzed $\mathrm{N}$ and $\mathrm{P}$ losses from food production including crop

Received: November 29, 2017

Revised: April 17, 2018

Accepted: April 19, 2018

Published: April 19, 2018 

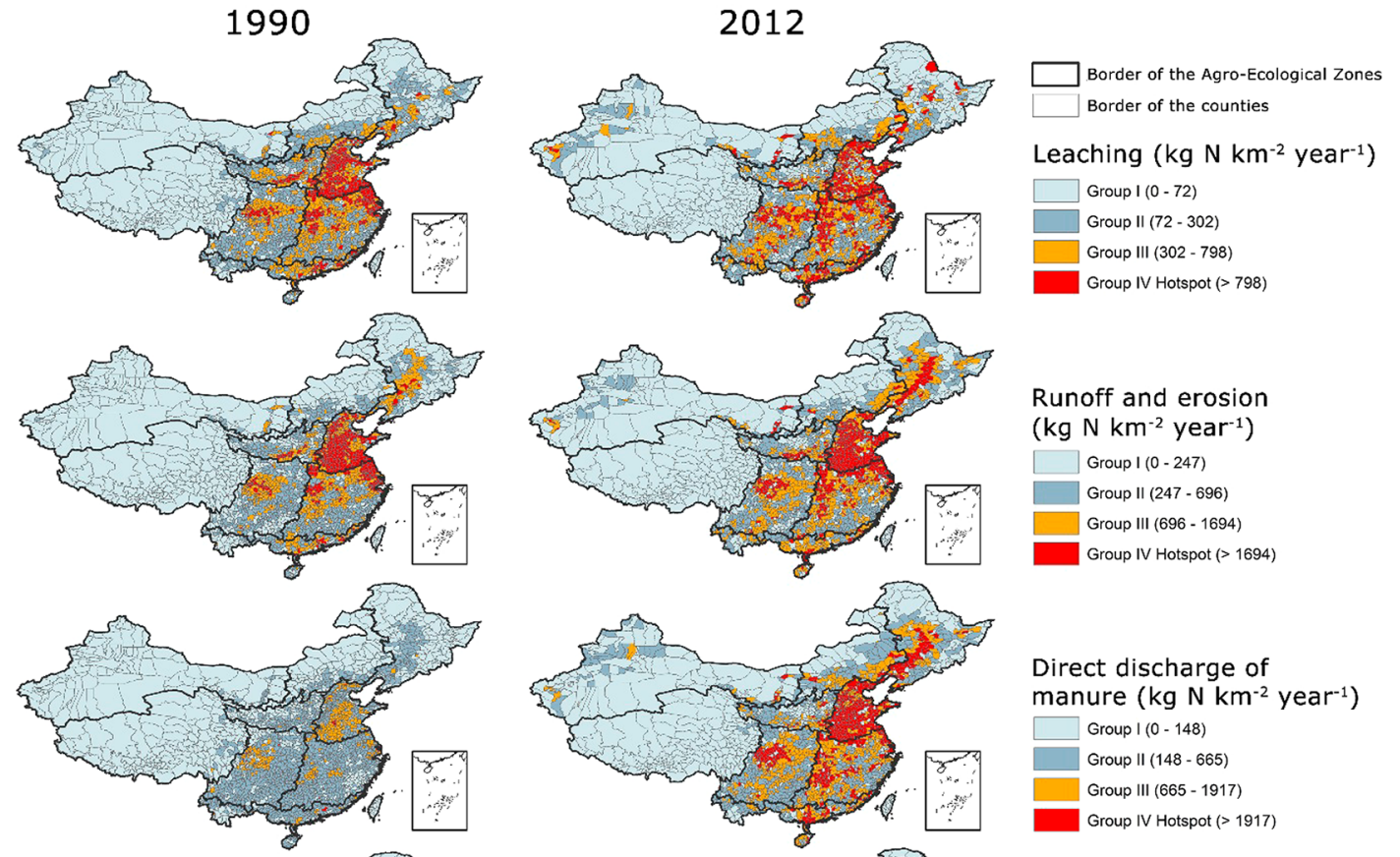

Direct discharge of manure $\left(\mathrm{kg} \mathrm{N} \mathrm{km}^{-2}\right.$ year $\left.{ }^{-1}\right)$

$\square$ Group ( (0-148)

$\square$ Group II (148-665)

Group III (665- 1917)
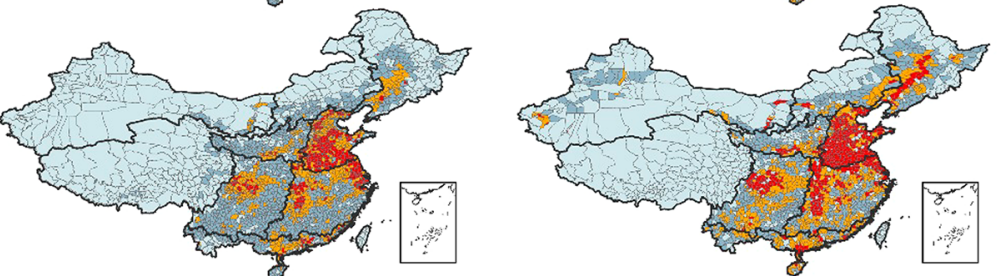

Group IV Hotspot (> 1917)
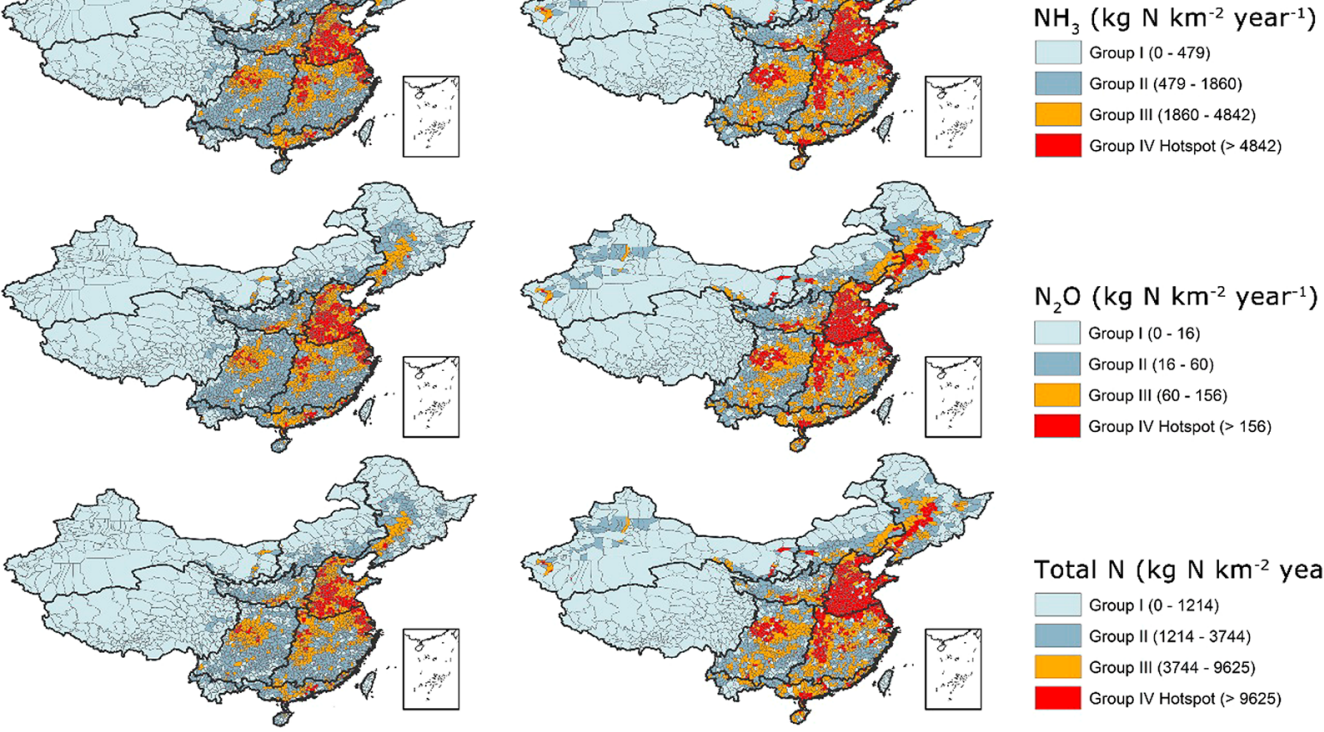

Total $\mathrm{N}\left(\mathrm{kg} \mathrm{N} \mathrm{km}{ }^{-2}\right.$ year $\left.^{-1}\right)$

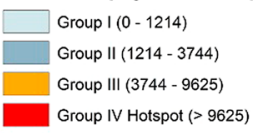

Figure 1. Nitrogen $(\mathrm{N})$ losses $\left(\mathrm{kg} \mathrm{N} \mathrm{km}^{-2}\right.$ year $\left.^{-1}\right)$ to the air and waters from leaching, runoff, and erosion, direct discharge of manure, ammonia $\left(\mathrm{NH}_{3}\right)$, and nitrous oxide $\left(\mathrm{N}_{2} \mathrm{O}\right)$ emissions, and the total $\mathrm{N}$ losses $\left(\mathrm{kg} \mathrm{N} \mathrm{km}^{-2}\right.$ year $\left.{ }^{-1}\right)$ from food production in 1990 and 2012 . The $\mathrm{N}$ losses were quantified using the NUFER model. The intervals for the four groups in this figure were defined based on quantiles $(25 \%, 50 \%, 75 \%)$ of $\mathrm{N}$ losses of all counties in 2012: group I (0-25\%), group II (25-50\%), group III (50-75\%), group IV (75-100\%). Counties in group IV were qualified as hotspots. The same information for 2000 is available in Figure S2. The names of the Agro-Ecological Zones are available in Figure S8.

and animal production for all Chinese counties in 1990, 2000, and 2012. We also quantified the associated $\mathrm{N}$ and $\mathrm{P}$ use efficiencies of food production in China to better understand the high losses in the hotspots. We compared several agricultural and socio-economic indicators for the hotspots with that for other counties in 2012. On the basis of the results, we conclude with suggestions on technologies and policies for nutrient pollution control in food production of China.

\section{MATERIALS AND METHODS}

NUFER Model. In this study we used the NUFER ${ }^{17,28}$ model to quantify $\mathrm{N}$ and $\mathrm{P}$ losses from food production for all counties in China for 1990, 2000, and 2012. Food production includes crop and animal production in this study (Figure S1 in Supporting Information). Years 1990, 2000, and 2012 were selected to reflect the period during which the transition of food production in agriculture from traditional small scale to intensive large scale took place in China (see section S1 in the Supporting Information for more information about the transition). The original NUFER model was developed by Ma et $\mathrm{al}^{28}$ to quantify $\mathrm{N}$ and $\mathrm{P}$ flows in the food production, processing and consumption chain of China using a mass balance approach. This model calculates nutrient flows at the national level for each year from 1980 to 2010, and for the year 
1990
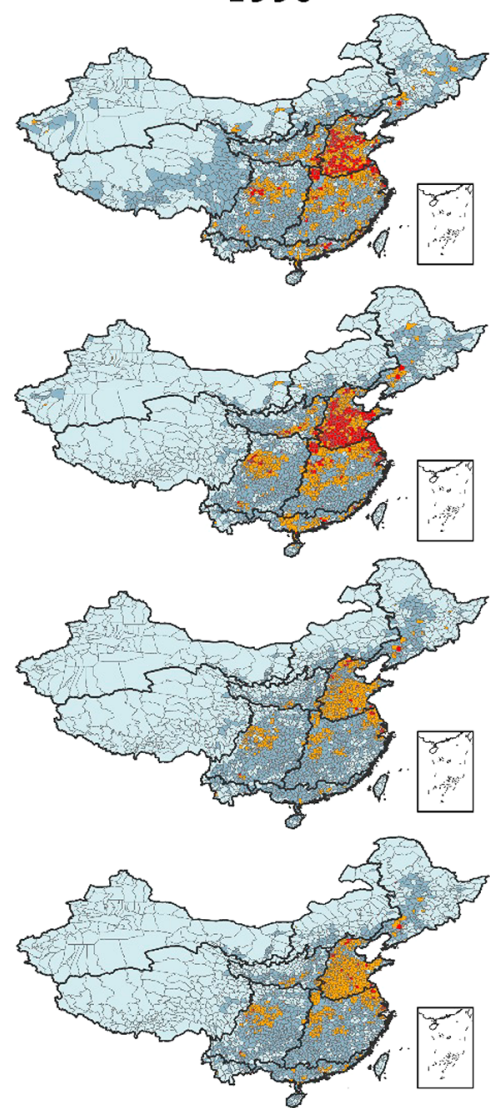

2012
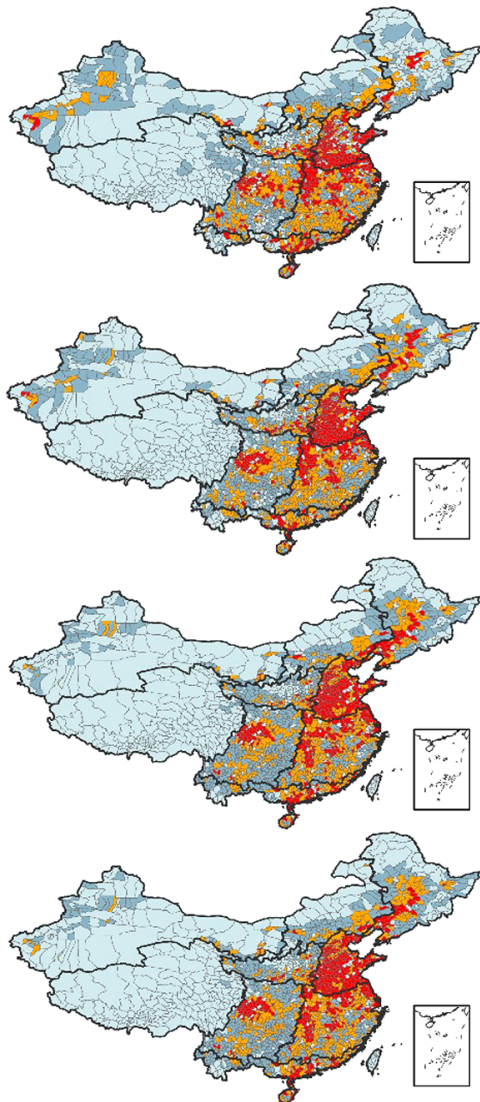

Direct discharge of

manure $\left(\mathrm{kg} \mathrm{P} \mathrm{km}^{-2}\right.$ year $\left.{ }^{-1}\right)$

$\square$ Group I ( 0 - 42) Group II (42 - 196) Group III (196 - 742)

Group IV Hotspot (> 742)

Runoff and erosion

(kg P km-2 year $^{-1}$ )

Group I (0 - 9)

Group III (47 - 140)

Group IV Hotspot (> 140)

Total P (kg P km-2 year $^{-1}$ )

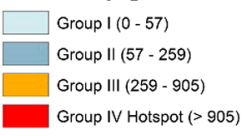

Group II (9 - 47)

Figure 2. Phosphorus $(\mathrm{P})$ losses $\left(\mathrm{kg} \mathrm{P} \mathrm{km}^{-2} \mathrm{year}^{-1}\right)$ to waters from leaching, runoff and erosion, direct discharge of manure, and the total $\mathrm{P}$ losses $\left(\mathrm{kg} \mathrm{P} \mathrm{km}^{-2}\right.$ year $\left.^{-1}\right)$ from food production in 1990 and 2012. The P losses were quantified using the NUFER model. The intervals for the four groups in this figure were defined based on quantiles $(25 \%, 50 \%, 75 \%)$ of P losses of all counties in 2012: group I (0-25\%), group II (25-50\%), group III $(50-75 \%)$, group IV $(75-100 \%)$. Counties in group IV were qualified as hotspots. The same information for 2000 is available in Figure S3. The names of the Agro-Ecological Zones are available in Figure S8.

2030. In addition, regional nutrient flows can be calculated for 31 provinces for 2005 and 2013. Detailed model description on the original NUFER model is available in section S2 in the Supporting Information. We developed and applied NUFER for all Chinese counties using county information, ${ }^{29}$ which was not done before. We also improved NUFER by including dry atmospheric $\mathrm{N}$ deposition on arable land that was not included in the original model. We described in section S2 in the Supporting Information how we included dry atmospheric N deposition and applied NUFER to the county scale.

Identifying Hotspots. We quantified the $\mathrm{N}$ and $\mathrm{P}$ losses to waters and the air from food production including crop and animal production systems using NUFER. The losses to waters are the $\mathrm{N}$ and $\mathrm{P}$ losses from leaching, surface runoff, and erosion in crop production, and $\mathrm{N}$ and $\mathrm{P}$ losses from direct discharge of animal manure in animal production. For the losses to the air, we calculated the emissions of ammonia $\left(\mathrm{NH}_{3}\right)$ and nitrous oxide $\left(\mathrm{N}_{2} \mathrm{O}\right)$ from crop and animal production systems. The details in the calculation of $\mathrm{N}$ and $\mathrm{P}$ losses using NUFER are available in section $\mathrm{S} 2$ in the Supporting Information. The calculated $\mathrm{N}$ and $\mathrm{P}$ losses in all counties were averaged by the area of the counties and were grouped into four groups (Figures 1 and 2). The intervals for the four groups were defined based on quantiles $(25 \%, 50 \%$, $75 \%)$ of the averaged $\mathrm{N}$ and $\mathrm{P}$ losses of all counties in 2012: group I (0-25\%), group II (25-50\%), group III (50-75\%), group IV (75-100\%, hotspot). The top $25 \%$ were considered hotspots. For 1990, 2000, and 2012 counties were considered as hotspots if their $\mathrm{N}$ and $\mathrm{P}$ losses fall within the range of the top $25 \%$ for 2012 . Thus, for all three years counties that have total $\mathrm{N}$ losses exceeding $9625 \mathrm{~kg} \mathrm{~N} \mathrm{~km}^{-2}$ year $^{-1}$ were qualified as hotspots (Figures 1 and S2). For P, counties with total losses of more than $905 \mathrm{~kg} \mathrm{P} \mathrm{km}{ }^{-2}$ year $^{-1}$ were qualified as hotspots (Figures 2 and S3). We did not identify hotspots based on water or air quality standards in China, because these standards differ among regions (e.g., provinces) and the use of the water body. For example, the water quality standards for drinking water supply differ from standards for water that are used for agricultural purposes. Therefore, we used the top 25\% for 2012 as a basis for the identification of hotspots as shown in Figures 1 and 2. We also calculated the associated $\mathrm{N}$ and $\mathrm{P}$ use efficiencies of food production for a better understanding of $\mathrm{N}$ and $\mathrm{P}$ losses. $\mathrm{N}$ and $\mathrm{P}$ use efficiencies were calculated as outputs of $\mathrm{N}$ and $\mathrm{P}$ via main products divided by the total inputs of $\mathrm{N}$ and $\mathrm{P}$ to this system (Box S3).

We included in our result (Figures 1, 2, S2, and S3) borders of the nine Agro-Ecological Zones (AEZs) in China to illustrate the spatial distribution of the hotspots for $\mathrm{N}$ and $\mathrm{P}$ losses. The AEZs are Northeast China, Inner Mongolia and Great Wall Vicinity, North China Plain, Loess Plateau, Middle and Lower Yangtze River, Southwest China, South China, Gansu and Xinjiang, and Tibetan Plateau (see Figure S8 for the location of the AEZs). These zones were defined by Sun and Shen ${ }^{30}$ based on their similarities in crop production (e.g., crop land, crop 
(A)
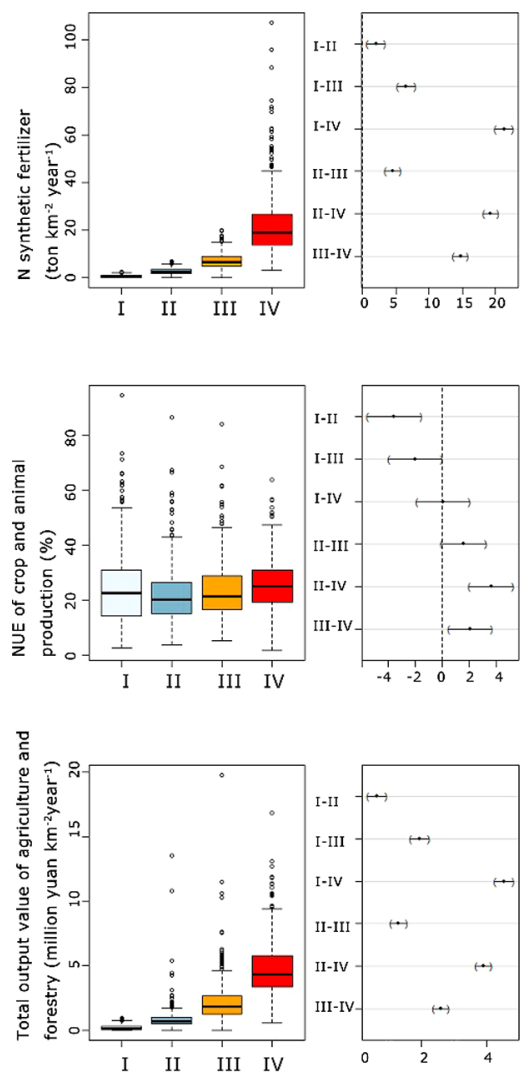

(A)
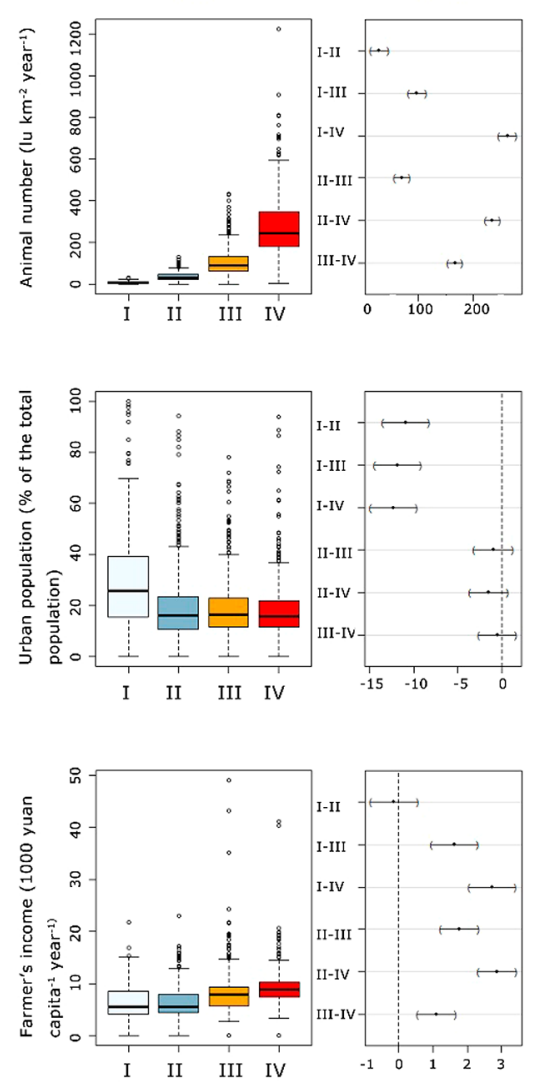

(A)
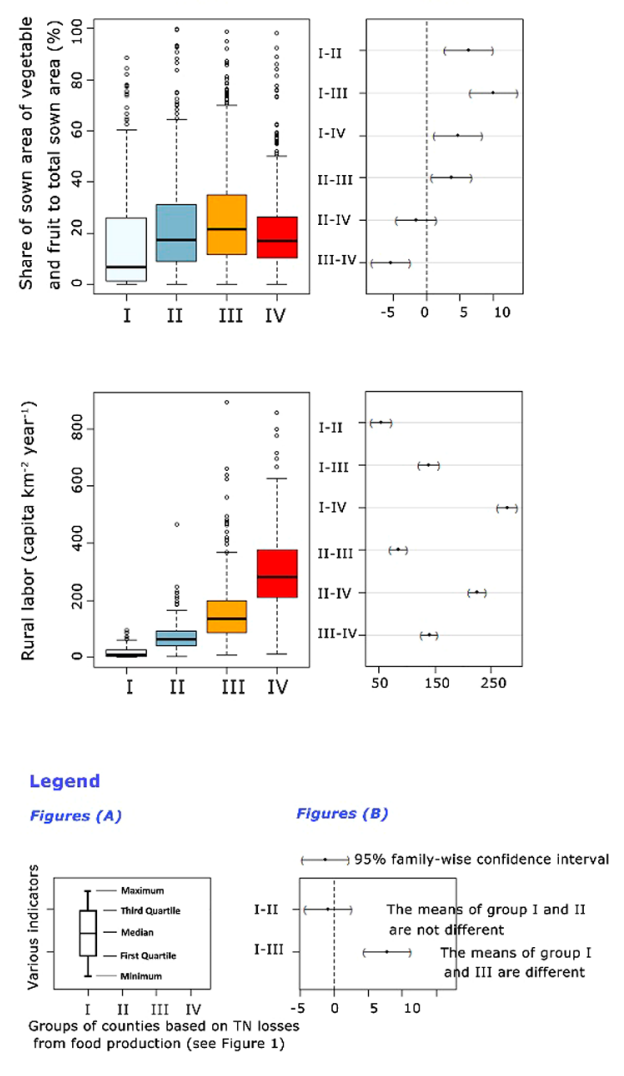

Figure 3. Boxplots for nitrogen $(\mathrm{N})$ : synthetic fertilizer (ton $\mathrm{km}^{-2}$ year $^{-1}$ ), animal number in livestock unit (lu km $\mathrm{km}^{-2}$ year ${ }^{-1}$, see Supporting Information for converting animal numbers in livestock unit), share of sown area of vegetable and fruit to the total sown area (\%), $\mathrm{N}$ use efficiency (NUE) of food production, urban population (\% of the total population), rural labor (capita $\mathrm{km}^{-2}$ year ${ }^{-1}$ ), total output value of agriculture and forestry (billion yuan $\mathrm{km}^{-2}$ year $^{-1}$ ), and farmers' incomes (1000 yuan capita ${ }^{-1}$ year $^{-1}$ ) among the four groups of total N losses (see Figure 1) in 2012 (A), and the pairwise comparisons from Tukey's Honest Significant Difference (Tukey's HSD) among the four groups (B). In B panels any 95\% confidence intervals that do not contain 0 provide evidence of a difference in the groups.

types) and animal production (e.g., animal type, animal numbers) systems.

Comparing Agricultural and Socio-economic Indicators in Hotspots with Nonhotspots. We compared several agricultural and socio-economic indicators in hotspots (group IV in Figures 1 and 2, and in Figures S2 and S3) and nonhotspot counties (groups I, II, III in Figures 1 and 2, and in Figures S2 and S3) in 1990 and 2012. The agricultural indicators are (i) $\mathrm{N}$ and $\mathrm{P}$ inputs to cropland from synthetic fertilizer, (ii) animal numbers, (iii) share of sown area of vegetable and fruit to total sown area, and (iv) $\mathrm{N}$ and $\mathrm{P}$ use efficiencies of food production including crop and animal production. The socio-economic indicators are (i) urban population, (ii) rural labor, (iii) total output value of agriculture and forestry, and (iv) farmers' incomes. We selected all socioeconomic indicators that are available in county statistics. The Tukey's Honest Significant Difference (Tukey's HSD) method was used to make pairwise comparisons of the agricultural and socio-economic indicators among the groups I, II, III, and IV that was defined above. The results of Tukey's HSD comparison are shown in Figures 3 and 4, and in Figures S4 and S5.

\section{RESULTS}

Hotspots for $\mathbf{N}$ and $\mathrm{P}$ Losses. The $\mathrm{N}$ and P losses increased fast between 1990 and 2012. As a result, the hotspot area in China expanded during this period. The hotspot area for total $\mathrm{N}$ losses increased by a factor of 3 (from 307850 to $828205 \mathrm{~km}^{2}$ ), and for total P by a factor of 24 (from 35355 to $861781 \mathrm{~km}^{2}$ ) between 1990 and 2012 (Table S6). The hotspots covered less than $5 \%$ of total land and contributed to $28 \%$ of total $\mathrm{N}$ losses, and $10 \%$ of total $\mathrm{P}$ losses in food production of China in 1990. In 2012, the hotspot area for total $\mathrm{N}$ and total P losses expanded to $9 \%$ of the total land in China. Astoundingly, these hotspots contributed more than half of nutrient losses ( $52 \%$ of total $\mathrm{N}$ losses, and $62 \%$ of total $\mathrm{P}$ losses) in this year. The increase in hotspot area and in contributions to total losses in China by hotspots are also calculated for $\mathrm{N}$ and $\mathrm{P}$ losses from various sources in Figures 1 and 2 and Table S6.

The spatial distribution of hotspots also changed between 1990 and 2012. In 1990, most hotspots are found in the North China Plain, and in the northeastern part of the Middle and Lower Yangtze River (Figures 1 and 2). In 2012, the hotspots expanded to cover a larger area of the North China Plain. Some counties in the AEZs Middle and Lower Yangtze River, Northeast China, Loess Plateau, Southwest China, and South China also show high $\mathrm{N}$ and $\mathrm{P}$ losses as hotspots. In the AEZs where the hotspot areas expanded, the food production is intensive and increased fast between 1990 and 2012 (Figure S9). The nonhotspots with low $\mathrm{N}$ and P losses (groups I and II in Figures 1 and 2) are found across northern and western 
(A)
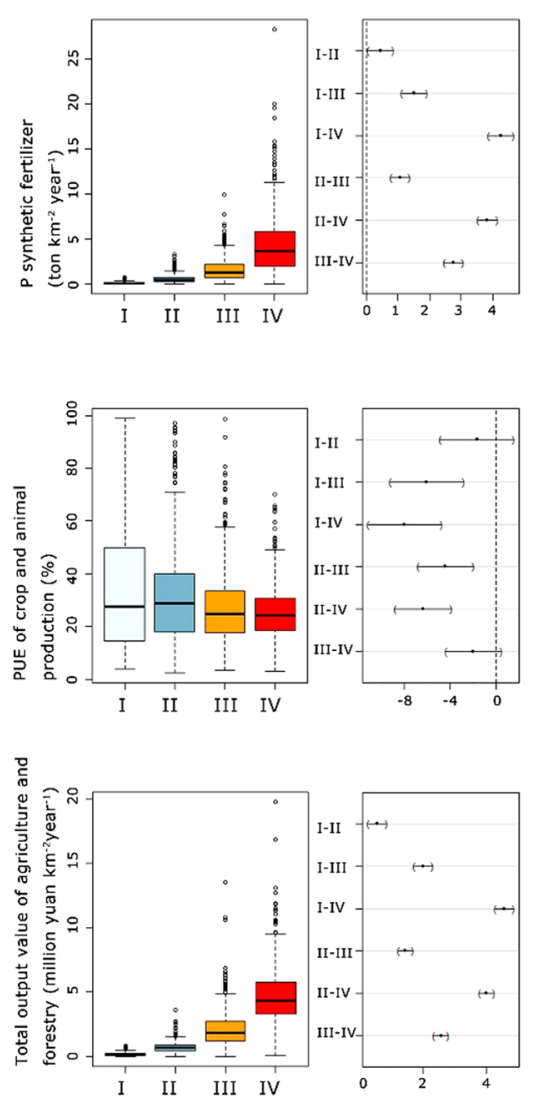

(A)
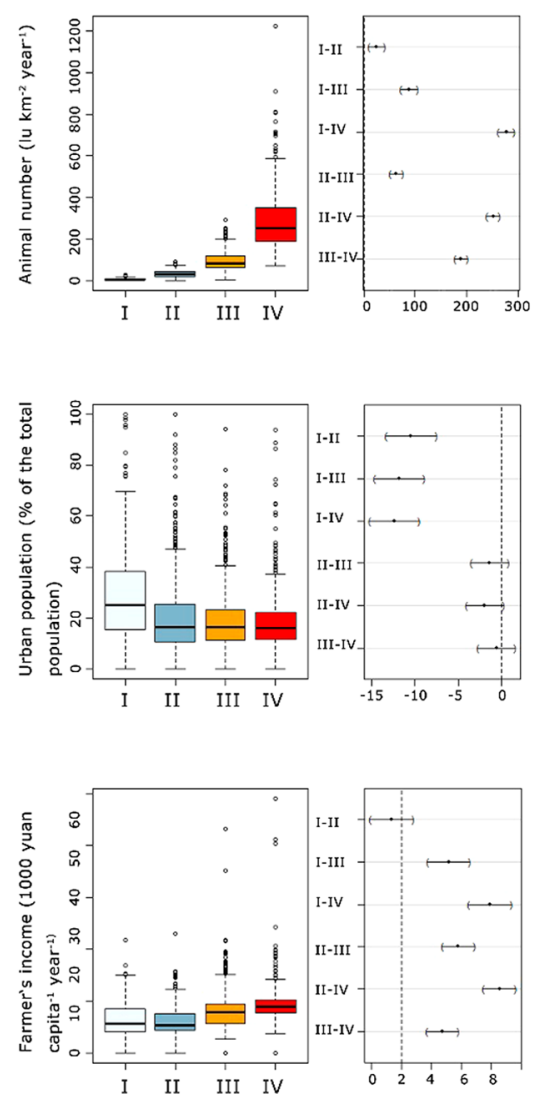

(A)
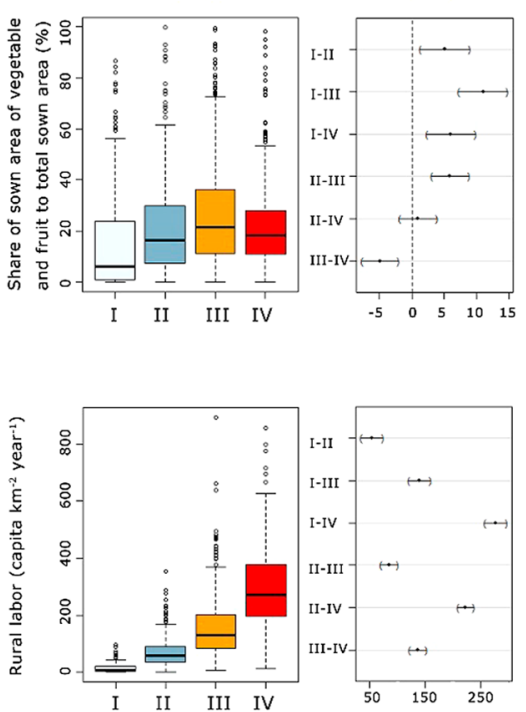

Legend

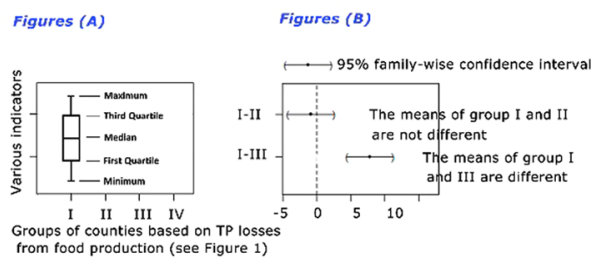

Figure 4. Boxplots of for phosphorus (P): synthetic fertilizer (ton $\mathrm{km}^{-2}$ year $^{-1}$ ), animal number in livestock unit $\left(\mathrm{lu} \mathrm{km} \mathrm{kear}^{-1}\right.$, see Supporting Information for converting animal numbers in livestock unit), share of sown area of vegetable and fruit to the total sown area (\%), P use efficiency (PUE) of food production, urban population (\% of the total population), rural labor (capita $\mathrm{km}^{-2}$ year $^{-1}$ ), total output value of agriculture and forestry (billion yuan $\mathrm{km}^{-2}$ year $^{-1}$ ), and farmers' incomes (1000 yuan capita ${ }^{-1}$ year $^{-1}$ ) among the four groups of total P losses (see Figure 2) in 2012 (A), and the pairwise comparisons from Tukey's Honest Significant Difference (Tukey's HSD) among the four groups (B). In B panels any 95\% confidence intervals that do not contain 0 provide evidence of a difference in the groups.

China in 2012, for example, in AEZs Inner Mongolia and Great Wall Vicinity, Gansu and Xinjiang, and Tibetan Plateau where food production is less intensive (Figure S9).

The result also shows that direct discharge of animal manure to waters in the hotspots became a more important source of $\mathrm{N}$ and P losses in food production over the last 30 years. In 1990, the hotspots for $\mathrm{N}$ and $\mathrm{P}$ losses to waters from direct discharge of manure only covered $0.2 \%$ and $0.3 \%$ of the total land. These hotspots were responsible for less than $10 \%$ of the total $\mathrm{N}$ and $\mathrm{P}$ losses from discharge of manure (Table S6). However, in 2012 the hotspots area for direct discharge of manure is calculated to increase by a factor of 51 for $\mathrm{N}$ losses and of 33 for P losses comparing to 1990. And these hotspots contributed to more than half of $\mathrm{N}$ and $\mathrm{P}$ losses (57\% for $\mathrm{N}$ and $64 \%$ for P) from direct discharge of manure in China (Table S6). This change in $\mathrm{N}$ and $\mathrm{P}$ losses from direct discharge of animal manure could be related to the transition of food production in China started in 1990s (section S1, Figures S6 and S7). ${ }^{31,32}$ Traditional-oriented food production was dominant in the 1990s. Traditional animal systems are small in size and combined with crop production. Animal manure is usually used as organic fertilizers for crops. Therefore, the discharge of manure to waters is relatively low. ${ }^{33-35}$ Industrial, highly intensive systems dominate food production in China since 2000s. Industrial animal production systems are large in size and are separated from crop production. The animal manure is usually collected, and discharged to surface waters or landfills without treatment. ${ }^{26,31,33-35}$ Therefore, the discharge of manure to waters has been increasing since 2000 particularly in the counties that have intensive animal production activities. Our results in Figures S6 and S7 indicate that intensive animal production in the hotspots is considerably higher than that in nonhotspot counties $(P<0.05)$. This situation lasted at least until the 'Regulation on the Prevention and Control of Pollution from Large-Scale Breeding of Livestock and Poultry' was introduced by Chinese Premier $\mathrm{Li}^{36}$ and implemented since 1 January 2014. By introducing this policy, the Chinese government aims to improve manure management and manure recycling in order to reduce the environmental pollution caused by intensive animal production. The "Livestock and Poultry Manure Utilization Action Program (2017-2020)” was introduced by $\mathrm{MOA}^{37}$ in late 2017. As a result, the direct discharge of animal manure may become smaller in the future. Our results present the situation in 2012, when policies on manure management were not widely introduced and not very effective.

Agricultural and Socio-economic Indicators. Comparing the hotspots with nonhotspot counties shows that food production in the hotspots was more intensive than in other counties (Figures 3 and 4, Figures S4 and S5, $P<0.05$ ) in both past (1990) and recent (2012) years. The mean synthetic fertilizer use and mean animal numbers in the hotspots were 
Table 1. Comparison of $\mathrm{N}$ and $\mathrm{P}$ Losses $\left(\mathrm{Tg} \mathrm{year}^{-1}\right)$ to the Air and Waters from Food Production Including Crop and Animal Production in China by Our Study with Estimates by Other Published Studies

\begin{tabular}{|c|c|c|c|c|c|c|c|c|}
\hline $\mathrm{N}$ or $\mathrm{P}$ losses $\left(\mathrm{Tg}\right.$ year $\left.^{-1}\right)$ & studies & system boundary & 2000 & 2006 & 2007 & 2008 & 2010 & 2012 \\
\hline \multirow[t]{10}{*}{$\mathrm{NH}_{3}$} & This study & food production & 11.3 & & & & & 13.5 \\
\hline & Huang et $\mathrm{al}^{43}$ & food production & & 9.2 & & & & \\
\hline & Gu et $\mathrm{al}^{44}$ & food production & & & & & 12.3 & \\
\hline & Crippa et al. ${ }^{45}$ & food production & 9.5 & & & & 12.5 & \\
\hline & Dianwu and Anpu ${ }^{46}$ & food production $(76 \%)+$ other & 13.6 & & & & & \\
\hline & Streets et al. $^{47}$ & food production $(80 \%)+$ other $(20 \%)$ & 13.6 & & & & & \\
\hline & Gu et al. $^{48}$ & food production $(88 \%)+$ other & & & & 11.2 & & \\
\hline & Ti et al. ${ }^{49}$ & food production + other & 10 & & 9.8 & & & \\
\hline & Cui et al. ${ }^{50}$ & food production + other & & & & & 10 & \\
\hline & Kurokawa et al. $^{51}$ & food production $(80 \%)+$ other $(20 \%)$ & 12.5 & 14.3 & & 14.8 & & \\
\hline \multirow[t]{6}{*}{$\mathrm{N}_{2} \mathrm{O}$} & This study & food production & 0.4 & & & & & 0.4 \\
\hline & Zhou et al. ${ }^{52}$ & food production & & & & $1.4^{a}$ & & \\
\hline & Gu et $\mathrm{al}^{44}$ & food production & & & & & 0.4 & \\
\hline & Crippa et $\mathrm{al}^{45}$ & food production & 0.6 & & & & & 0.9 \\
\hline & Gu et $\mathrm{al}^{48}$ & food production $(45 \%)+$ other & & & & 1.1 & & \\
\hline & Cui et al..$^{50}$ & food production + other & & & & & 0.4 & \\
\hline \multirow[t]{5}{*}{ Total $\mathrm{N}$ to waters } & This study & food production & 9.2 & & & & & 12.8 \\
\hline & Gu et $\mathrm{al}^{44}$ & food production & & & & & 7.8 & \\
\hline & Strokal et al. $^{32}$ & food production (six river basins) & 8.5 & & & & & \\
\hline & Ti et al. ${ }^{49}$ & food production + other & 8.8 & & 9.3 & & & \\
\hline & Cui et al..$^{50}$ & food production + other & & & & & 12 & \\
\hline \multirow[t]{3}{*}{ Total $P$ to waters } & This study & food production & 1.5 & & & & & 2.5 \\
\hline & Strokal et al. ${ }^{32}$ & food production & 1.3 & & & & & \\
\hline & Liu et al. ${ }^{53}$ & food production + other & & & & & & 1.7 \\
\hline
\end{tabular}

${ }^{a}$ This study accounts for nitrous oxide $\left(\mathrm{N}_{2} \mathrm{O}\right)$ emissions from the burning of straw (0.5), which we do not consider. However, our results shows similar spatial patterns to those in this study.

much higher than in other counties in 2012 (Figures 3 and 4, $P$ $<0.05)$. For example, the mean synthetic fertilizer input in the hotspots was $400 \%$ higher for N, and $300 \%$ higher for P than that in other counties (Table S7). Mean animal numbers in the hotspots were five times that in other counties in 2012 (Table S7).

The $\mathrm{N}$ and $\mathrm{P}$ use efficiencies of food production are calculated to be low and their means are comparable between hotspots and nonhotspot counties (Figures 3 and 4, Figures S4 and S5, $P>0.05)$. The average nutrient use efficiency of food production in Chinese counties was $24 \%$ for $\mathrm{N}$, and $29 \%$ for $\mathrm{P}$ in 2012 (Table S7). This is lower than the nutrient use efficiency in 1990 that was $25 \%$ for $\mathrm{N}$ and $38 \%$ for P (Figures S4 and S5). Howarth et al. ${ }^{38}$ estimated the $\mathrm{N}$ use efficiency of main crop production at 56\% in United States in 2000. And in Europe the $\mathrm{N}$ use efficiency of main crop production was around $44 \%$ in $2000 .{ }^{39}$ This indicates that in general the nutrient inputs in food production in China are not used efficiently because of poor nutrient management in food production, and as a consequence losses of nutrients to the air and waters are relatively high. However, the fact that nutrient use efficiencies in hotspots do not differ from those in nonhotspots, indicates that low $\mathrm{N}$ and $\mathrm{P}$ use efficiencies are not the only reason for the high losses in the hotspots. The high $\mathrm{N}$ and $\mathrm{P}$ losses are the net effect of low $\mathrm{N}$ and $\mathrm{P}$ use efficiencies, intensive food production (e.g., large animal numbers), and poor nutrient management technologies (e.g., overuse of synthetic fertilizer, and high direct discharge of manure to waters as mentioned above) in the hotspots.

The shares of vegetables and fruits in the total sown area in the hotspots are comparable to that in nonhotspot counties (Figures 3 and 4,Figures S4 and S5, $P>0.05$ ). Production of vegetables and fruit was not found to be more intensive in hotspots than in other counties. This is surprising since earlier studies indicate that nutrient losses from fruit and vegetable production are usually higher than that in other cropping systems as a result of high synthetic fertilizer application.

Socio-economic indicators also differ between hotspots and other counties (Figures 3 and 4, Figures S4 and S5, $P<0.05$ ). Hotspots are less urbanized. On average less than $20 \%$ of population was urban in the hotspots in 2012 (Table S7). On the other hand, the mean number of people working in food production in hotspots was three times that in nonhotspot counties in 2012 (Table S7). The mean incomes for farmers who work in food production were over $30 \%$ higher in the hotspots than that in the nonhotspot counties (Table S7). Also the mean total output value from agriculture and forestry in these hotspots was considerably higher (close to five times) than in other counties in 2012 (Figures 3 and $4, P<0.05$ ). Therefore, farmers' incomes in the hotspots seem to be more dependent on food production.

\section{DISCUSSION}

This study is the first to calculate past (1990 and 2000) and more recent (2012) $\mathrm{N}$ and $\mathrm{P}$ losses to the environment from food production in China at the county scale. On this basis we identified the associated hotspots for $\mathrm{N}$ and $\mathrm{P}$ losses from food production. We compared several agricultural and socioeconomic indicators for the hotspots with that for other counties in 2012. The main findings are as follows.

We calculate a larger hotspot area for 2012 than for 1990, indicating $\mathrm{N}$ and $\mathrm{P}$ losses from food production increased in this period. In 2012, the hotspots covered $9 \%$ of the total land, but were responsible for $52 \%$ of total $\mathrm{N}$ losses and $62 \%$ of total 
P losses in China. Nutrient losses from food production in the hotspots are higher than $9625 \mathrm{~kg} \mathrm{~km}^{-1}$ for $\mathrm{N}$, and $905 \mathrm{~kg} \mathrm{~km}^{-1}$ for P. Note that these losses are even higher than the recommended fertilizer inputs to arable land. For example, the United Kingdom suggests to apply $120-270 \mathrm{~kg} \mathrm{ha}^{-1} \mathrm{~N}$ on arable land. ${ }^{54}$ Such high losses to the air and waters pose potentially high risks to the environment. The direct discharge of animal manure has become an important source of $\mathrm{N}$ and $\mathrm{P}$ losses in food production over the last 30 years as the result of industrialization of animal production in China as indicated in Table S9.

The hotspots expanded from part of North China in 1990 to most of the area of North China Plain, and some areas of other eastern AEZs in 2012. Food production in the hotspots are found to be intensive. Mean synthetic fertilizer use and mean animal numbers in hotspots were $300-400 \%$ higher than that in nonhotspot counties in 2012. N and P use efficiencies of food production were generally low (24\% for NUE, and $29 \%$ for PUE) in 2012 and did not differ much between hotspots and nonhotspot counties. Therefore, low use efficiency of nutrients is not the only factor to explain the high losses of $\mathrm{N}$ and $\mathrm{P}$ in hotspots. The high losses of $\mathrm{N}$ and $\mathrm{P}$ in the hotspots are the net effect of the low $\mathrm{N}$ and $\mathrm{P}$ use efficiencies, and the intensive food production in these counties. Less than $20 \%$ of the population is urban in hotspots in 2012. The mean number of people working in food production in hotspots was three times that in other counties in 2012. The mean total output value from agriculture and forestry in hotspots was considerably higher than that in other counties in 2012. Therefore, farmers' incomes in hotspots seem to be more dependent on food production than other counties.

Uncertainties in our analysis are mainly related to the model inputs and the coefficients that are used in the model calculation. In this study, we used county data from the Chinese statistical year book as inputs to NUFER. Some of the model inputs were missing in this data set. For the incomplete information, the provincial data from Chinese statistical year book and China livestock yearbook were used as complement (see section S2 in the Supporting Information for more details). These statistical yearbooks are known to be the most reliable data source in China. The model coefficients (e.g., nutrient content in crops, nutrient loss factors) are from the original NUFER model, which was taken from other peer reviewed papers and interviews of farmers in China. ${ }^{28}$ Our results are comparable with other studies. For example, we estimated comparable $\mathrm{NH}_{3}$ losses from food production to the air, and $\mathrm{N}$ and $\mathrm{P}$ losses to waters at the national scale with many of the other studies (Table 1). Our estimates of $\mathrm{N}_{2} \mathrm{O}$ emission in 2012 is lower than in the other studies (Table 1). A likely explanation is that $\mathrm{N}_{2} \mathrm{O}$ emission from the burning of straw was not considered in our study. This can be improved in our model. However, we do not think this will lead to large change in our conclusions since $\mathrm{N}_{2} \mathrm{O}$ losses are minor compared to other losses of reactive $\mathrm{N}$ from food production (Figures 1 and 2). Huang et al., ${ }^{55}$ Kang et al., ${ }^{56}$ Zhang et al. ${ }^{57}$ calculated similar spatial distribution patterns for $\mathrm{NH}_{3}$ emissions as we did. The study of $\mathrm{Gu}$ et al. ${ }^{48}$ identified similar spatial distribution of $\mathrm{NH}_{3}$ and $\mathrm{N}_{2} \mathrm{O}$ emissions from food production and other human activities and calculated a considerable increase in these emissions between 1990 and 2010. Similar spatial distribution of $\mathrm{P}$ losses from food production and other sectors in 2012 was also identified by Liu et al. ${ }^{53}$
Opportunities to Reduce $\mathbf{N}$ and $\mathbf{P}$ Losses. Our results show that hotspots contributed to more than half of total $\mathrm{N}$ and total $\mathrm{P}$ losses from food production in China, while covering less than $10 \%$ of the country area in 2012 . Thus, it is important to reduce the nutrient losses from food production in these hotspots in order to control nutrient pollution in China. Region-specific nutrient management needs to be developed for the hotspots particularly for the North China Plain where $\mathrm{N}$ and $\mathrm{P}$ losses are relatively high, and the food production activities are more intensive than other regions. By comparing the socio-economic indicators in hotspots and nonhotspots, we found that farmers' incomes in hotspots are more dependent on food production. Therefore, the production of food in the hotspots needs a transformation in order to avoid negative effects of pollution on the economies of local societies.

There are many technical improvements possible to reduce losses of nutrients. In crop production, techniques that help to fertilize crops based on their specific needs could reduce $\mathrm{N}$ and $\mathrm{P}$ inputs to land by up to $20 \%$, and improve the associate nutrient use efficiencies in the hotspots. ${ }^{13,58-60}$ Increasing farm sizes may also decrease the use of synthetic fertilizer in crop production. ${ }^{61}$ Nutrient losses to the air and waters could be reduced by up to $60 \%$ for $\mathrm{N}$, and $85 \%$ for $\mathrm{P}$ without reducing crop yields, needed to meet the increasing food demand in China. ${ }^{60}$ This also secures the interests of farmers since their incomes are dependent on food production. Low-emission technologies (e.g., inject animal manure into soil) could be adopted to reduce the $\mathrm{NH}_{3}$ and $\mathrm{N}_{2} \mathrm{O}$ emission from applying fertilizers on cropland. ${ }^{26,62,63}$ Experimental and modeling studies $^{58,59,64,65}$ that explore and implement the abovementioned techniques in the North China Plain could be used as a good basis for the nutrient management in hotspots. The intensive industrial animal production leads to large $\mathrm{N}$ and $\mathrm{P}$ losses to the environment in the hotspots. Technologies that improve the quality of animal feed could reduce $20-30 \%$ of the $\mathrm{N}$ and $\mathrm{P}$ excretion, ${ }^{39,66,67}$ thus reduce the overall $\mathrm{N}$ and $\mathrm{P}$ losses from animal production. The $\mathrm{N}$ and $\mathrm{P}$ losses to waters from direct discharge of manure could be much reduced by up to $85 \%$ via recycling animal manure on cropland as organic fertilizers and by improving the treatment of animal manure before discharging. ${ }^{60,68}$ The $\mathrm{N}$ and $\mathrm{P}$ losses to the air from animal production can be reduced in several ways, for instance by shifting to low emission housing and manure storage technologies that are currently used in some European Union (EU) countries. ${ }^{69}$ The above nutrient management options are technically effective in reducing $\mathrm{N}$ and $\mathrm{P}$ losses. In future analyses, it is important to also explore whether these options are economically affordable, because implementation of these options may be a challenge in China.

In summary, our study can be used to identify hotspot counties where pollution control technologies are needed to reduce $\mathrm{N}$ and $\mathrm{P}$ losses from food production. This holds in particular for technologies to reduce synthetic fertilizer use, to improve nutrient use efficiencies of food production, to reduce emission of $\mathrm{N}$ in animal housing and manure storage, and to increase recycling of manure on land. The challenge will be to secure food production so that farmers' interests are not negatively affected by pollution control.

\section{ASSOCIATED CONTENT}

\section{S Supporting Information}

The Supporting Information is available free of charge on the ACS Publications website at DOI: 10.1021/acs.est.7b06138. 
This file includes detailed calculation methods, tables, and figures of additional data (Figures S1 to S9, Tables S1 to S9, Boxes S1 to S3, and References) (PDF)

\section{AUTHOR INFORMATION}

\section{Corresponding Authors}

*Phone/Fax: +31 317 483776. E-mail: mengru.wang@wur.nl. *Phone/Fax: 86-0-311-85810877. E-mail: malin1979@sjziam. ac.cn.

\section{ORCID $\odot$}

Lin Ma: 0000-0003-1761-0158

Notes

The authors declare no competing financial interest.

\section{ACKNOWLEDGMENTS}

We gratefully acknowledge the sponsors of this research: National Key Research and Development Program of China (2016YFD0800106), Wageningen Institute for Environment and Climate Research (WIMEK) of Wageningen University \& Research, Chinese National Basic Research Program (2015CB150405), the National Natural Science Foundation of China (31572210), President's International Fellowship Initiative, PIFI of the Chinese Academy of Science (2015VEA025), the Hundred Talent Program of the Chinese Academy of Science, and the Distinguished Young Scientists Project of Natural Science Foundation of Hebei (D2017503023). We would like to thank Dr. Zhaohai Bai for constructive comments and suggestions, and Dr. Zhanqing Zhao for advice in programming to process the county information.

\section{REFERENCES}

(1) Mosier, A.; Syers, J. K.; Freney, J. R. Agriculture and the Nitrogen Cycle: Assessing the Impacts of Fertilizer Use on Food Production and the Environment; Island Press, 2013; Vol. 65.

(2) Bouwman, L.; Goldewijk, K. K.; Van Der Hoek, K. W.; Beusen, A. H.; Van Vuuren, D. P.; Willems, J.; Rufino, M. C.; Stehfest, E. Exploring global changes in nitrogen and phosphorus cycles in agriculture induced by livestock production over the 1900-2050 period. Proc. Natl. Acad. Sci. U. S. A. 2013, 110 (52), 20882-20887.

(3) Tilman, D.; Balzer, C.; Hill, J.; Befort, B. L. Global food demand and the sustainable intensification of agriculture. Proc. Natl. Acad. Sci. U. S. A. 2011, 108 (50), 20260-20264.

(4) Zhang, F.; Chen, X.; Vitousek, P. Chinese agriculture: An experiment for the world. Nature 2013, 497 (7447), 33-35.

(5) Reay, D. S.; Davidson, E. A.; Smith, K. A.; Smith, P.; Melillo, J. M.; Dentener, F.; Crutzen, P. J. Global agriculture and nitrous oxide emissions. Nat. Clim. Change 2012, 2 (6), 410-416.

(6) Conway, G. R.; Pretty, J. N. Unwelcome Harvest: Agriculture and Pollution. Routledge: 2013.

(7) Dumont, E.; Harrison, J.; Kroeze, C.; Bakker, E.; Seitzinger, S. Global distribution and sources of dissolved inorganic nitrogen export to the coastal zone: Results from a spatially explicit, global model. Global Biogeochem. Cycl. 2005, 19 (4), 2606.

(8) Seitzinger, S.; Mayorga, E.; Bouwman, A.; Kroeze, C.; Beusen, A.; Billen, G.; Van Drecht, G.; Dumont, E.; Fekete, B.; Garnier, J. Global river nutrient export: A scenario analysis of past and future trends. Global Biogeochem. Cycl. 2010, 24 (4), 3587.

(9) Strokal, M.; Yang, H.; Zhang, Y.; Kroeze, C.; Li, L.; Luan, S.; Wang, H.; Yang, S.; Zhang, Y. Increasing eutrophication in the coastal seas of China from 1970 to 2050. Mar. Pollut. Bull. 2014, 85 (1), 123140.

(10) Strokal, M. P.; Kroeze, C.; Kopilevych, V. A.; Voytenko, L. V. Reducing future nutrient inputs to the Black Sea. Sci. Total Environ. 2014, 466, 253-264.
(11) Yasin, J. A.; Kroeze, C.; Mayorga, E. Nutrients export by rivers to the coastal waters of Africa: Past and future trends. Global Biogeochem. Cycl. 2010, 24 (4), 3568.

(12) Ma, L.; Zhang, W.; Ma, W.; Velthof, G.; Oenema, O.; Zhang, F. An analysis of developments and challenges in nutrient management in China. Journal of environmental quality 2013, 42, 951-961.

(13) Ma, L.; Wang, F.; Zhang, W.; Ma, W.; Velthof, G.; Qin, W.; Oenema, O.; Zhang, F. Environmental assessment of management options for nutrient flows in the food chain in China. Environ. Sci. Technol. 2013, 47 (13), 7260-7268.

(14) Lu, D.; Lu, F.; Pan, J.; Cui, Z.; Zou, C.; Chen, X.; He, M.; Wang, $Z$. The effects of cultivar and nitrogen management on wheat yield and nitrogen use efficiency in the North China Plain. Field Crops Research 2015, 171, 157-164.

(15) Li, H.; Liu, J.; Li, G.; Shen, J.; Bergström, L.; Zhang, F. Past, present, and future use of phosphorus in Chinese agriculture and its influence on phosphorus losses. Ambio 2015, 44 (2), 274-285.

(16) Hartmann, T. E.; Yue, S.; Schulz, R.; He, X.; Chen, X.; Zhang, F.; Müller, T. Yield and $\mathrm{N}$ use efficiency of a maize-wheat cropping system as affected by different fertilizer management strategies in a farmer's field of the North China Plain. Field Crops Research 2015, 174, $30-39$.

(17) Ma, L.; Velthof, G.; Wang, F.; Qin, W.; Zhang, W.; Liu, Z.; Zhang, Y.; Wei, J.; Lesschen, J.; Ma, W. Nitrogen and phosphorus use efficiencies and losses in the food chain in China at regional scales in 1980 and 2005. Sci. Total Environ. 2012, 434, 51-61.

(18) Ma, W.; Li, J.; Ma, L.; Wang, F.; Sisák, I.; Cushman, G.; Zhang, F. Nitrogen flow and use efficiency in production and utilization of wheat, rice, and maize in China. Agricultural Systems 2008, 99 (1), 5363.

(19) Wang, F.; Sims, J.; Ma, L.; Ma, W.; Dou, Z.; Zhang, F. The phosphorus footprint of China's food chain: implications for food security, natural resource management, and environmental quality. Journal of environmental quality 2011, 40 (4), 1081-1089.

(20) Li, X.; Hu, C.; Delgado, J. A.; Zhang, Y.; Ouyang, Z. Increased nitrogen use efficiencies as a key mitigation alternative to reduce nitrate leaching in north china plain. Agricultural Water Management 2007, 89 (1-2), 137-147.

(21) Qu, H. J.; Kroeze, C. Past and future trends in nutrients export by rivers to the coastal waters of China. Sci. Total Environ. 2010, 408 (9), 2075-2086.

(22) Hou, Y.; Ma, L.; Gao, Z. L.; Wang, F. H.; Sims, J. T.; Ma, W. Q.; Zhang, F. S. The Driving Forces for Nitrogen and Phosphorus Flows in the Food Chain of China, 1980 to 2010. J. Environ. Qual. 2013, 42 (4), 962-971.

(23) Zhu, Z.; Jin, J. Fertilizer use and food security in China. Plant Nutrition and Fertilizer Science 2013, 19 (2), 259-273.

(24) Wang, F.; Dou, Z.; Ma, L.; Ma, W.; Sims, J.; Zhang, F. Nitrogen mass flow in China's animal production system and environmental implications. J. Environ. Qual. 2010, 39 (5), 1537-1544.

(25) Chen, M.; Chen, J.; Sun, F. Agricultural phosphorus flow and its environmental impacts in China. Sci. Total Environ. 2008, 405 (1-3), $140-152$.

(26) Bai, Z.; Ma, L.; Qin, W.; Chen, Q.; Oenema, O.; Zhang, F. Changes in Pig Production in China and Their Effects on Nitrogen and Phosphorus Use and Losses. Environ. Sci. Technol. 2014, 48 (21), $12742-12749$.

(27) Liu, Y.; Mol, A. P. J.; Chen, J. Material Flow and Ecological Restructuring in China. J. Ind. Ecol. 2004, 8 (3), 103-120.

(28) Ma, L.; Ma, W.; Velthof, G.; Wang, F.; Qin, W.; Zhang, F.; Oenema, O. Modeling nutrient flows in the food chain of China. J. Environ. Qual. 2010, 39 (4), 1279-1289.

(29) RESDC. http://www.resdc.cn (accessed February 2015).

(30) Sun, H.; Shen, Y. Agricultural natural resources and regional development in China; Jiangsu Science and Technology Press, 1994.

(31) Chadwick, D.; Wei, J.; Yan'an, T.; Guanghui, Y.; Qirong, S.; Qing, C. Improving manure nutrient management towards sustainable agricultural intensification in China. Agric., Ecosyst. Environ. 2015, 209, 34-46. 
(32) Strokal, M.; Kroeze, C.; Wang, M.; Bai, Z.; Ma, L. The MARINA model (Model to Assess River Inputs of Nutrients to seAs): Model description and results for China. Sci. Total Environ. 2016, 562, 869-888.

(33) Wang, L. Modern Chinese Pig Production; Jindun Press: Beijing, 2007.

(34) Schneider, M., Feeding China's Pigs: Implications for the Environment, China's Smallholder Farmers and Food Security. Institute for Agriculture and Trade Policy, 2011.

(35) Bai, Z. H.; Ma, L.; Oenema, O.; Chen, Q.; Zhang, F. S. Nitrogen and Phosphorus Use Efficiencies in Dairy Production in China. J. Environ. Qual. 2013, 42 (4), 990-1001.

(36) Li, K., The Regulation on the Prevention and Control of Pollution from Large-scale Breeding of Livestock and Poultry; State Council of China, Beijing, China, 2014.

(37) Livestock and Poultry Manure Utilization Action Program; MOA: Beijing, China, 2017-2020

(38) Howarth, R. W.; Boyer, E. W.; Pabich, W. J.; Galloway, J. N. Nitrogen use in the United States from 1961-2000 and potential future trends. Ambio 2002, 31 (2), 88-96.

(39) Oenema, O.; Witzke, H.; Klimont, Z.; Lesschen, J.; Velthof, G. Integrated assessment of promising measures to decrease nitrogen losses from agriculture in EU-27. Agric., Ecosyst. Environ. 2009, 133 (3), 280-288.

(40) Bai, Z.; Ma, L.; Ma, W.; Qin, W.; Velthof, G. L.; Oenema, O.; Zhang, F. Changes in phosphorus use and losses in the food chain of China during 1950-2010 and forecasts for 2030. Nutr. Cycling Agroecosyst. 2016, 104 (3), 361-372.

(41) Chen, X.; Ma, L.; Ma, W.; Wu, Z.; Cui, Z.; Hou, Y.; Zhang, F. What has caused the use of fertilizers to skyrocket in China? Nutr. Cycling Agroecosyst. 2018, 110 (2), 241-255.

(42) Heffer, P.; Gruère, A.; Roberts, T. Assessment of Fertilizer Use by Crop at the Global Level. https://www.fertilizer.org//images/ Library_Downloads/2017_IFA_AgCom_17_134\%20rev_ FUBC\%20assessment\%202014.pdf (accessed January, 2003).

(43) Huang, X.; Song, Y.; Li, M.; Li, J.; Huo, Q.; Cai, X.; Zhu, T.; Hu, M.; Zhang, $\mathrm{H}$. A high - resolution ammonia emission inventory in China. Global Biogeochem. Cycl. 2012, 26 (1), 4161.

(44) Gu, B.; Ju, X.; Chang, J.; Ge, Y.; Vitousek, P. M. Integrated reactive nitrogen budgets and future trends in China. Proc. Natl. Acad. Sci. U. S. A. 2015, 112, 201510211.

(45) Crippa, M.; Janssens-Maenhout, G.; Dentener, F.; Guizzardi, D.; Sindelarova, K.; Muntean, M.; Van Dingenen, R.; Granier, C. Forty years of improvements in European air quality: regional policyindustry interactions with global impacts. Atmos. Chem. Phys. 2016, 16 (6), 3825-3841.

(46) Dianwu, Z.; Anpu, W. Estimation of anthropogenic ammonia emissions in asia. Atmos. Environ. 1994, 28 (4), 689-694.

(47) Streets, D. G.; Bond, T.; Carmichael, G.; Fernandes, S.; Fu, Q.; He, D.; Klimont, Z.; Nelson, S.; Tsai, N.; Wang, M. Q. An inventory of gaseous and primary aerosol emissions in Asia in the year 2000. J. Geophys. Res.: Atm. 2003, 108 (D21), 2093 DOI: 10.1029/ 2002JD003093.

(48) Gu, B. J.; Ge, Y.; Ren, Y.; Xu, B.; Luo, W. D.; Jiang, H.; Gu, B. H.; Chang, J. Atmospheric Reactive Nitrogen in China: Sources, Recent Trends, and Damage Costs. Environ. Sci. Technol. 2012, 46 (17), 9420-9427.

(49) Ti, C.; Pan, J.; Xia, Y.; Yan, X. A nitrogen budget of mainland China with spatial and temporal variation. Biogeochemistry 2012, 108 (1-3), 381-394.

(50) Cui, S.; Shi, Y.; Groffman, P. M.; Schlesinger, W. H.; Zhu, Y.-G. Centennial-scale analysis of the creation and fate of reactive nitrogen in China (1910-2010). Proc. Natl. Acad. Sci. U. S. A. 2013, 110, 2052.

(51) Kurokawa, J.; Ohara, T.; Morikawa, T.; Hanayama, S.; JanssensMaenhout, G.; Fukui, T.; Kawashima, K.; Akimoto, H. Emissions of air pollutants and greenhouse gases over Asian regions during 20002008: Regional Emission inventory in ASia (REAS) version 2. Atmos. Chem. Phys. 2013, 13 (21), 11019-11058.
(52) Zhou, F.; Shang, Z.; Ciais, P.; Tao, S.; Piao, S.; Raymond, P.; $\mathrm{He}$, C.; Li, B.; Wang, R.; Wang, X.; et al. A new high-resolution N2O emission inventory for China in 2008. Environ. Sci. Technol. 2014, 48 (15), 8538-8547.

(53) Liu, X.; Sheng, H.; Jiang, S.; Yuan, Z.; Zhang, C.; Elser, J. J. Intensification of phosphorus cycling in China since the 1600s. Proc. Natl. Acad. Sci. U. S. A. 2016, 113 (10), 2609-2614.

(54) GOVUK Using nitrogen fertilisers in nitrate vulnerable zones. https://www.gov.uk/guidance/using-nitrogen-fertilisers-in-nitratevulnerable-zones\#how-much-nitrogen-you-can-apply-to-your-crops (accessed January 2003).

(55) Huang, J.; Huang, Z.; Jia, X.; Hu, R.; Xiang, C. Long-term reduction of nitrogen fertilizer use through knowledge training in rice production in China. Agricultural Systems 2015, 135, 105-111.

(56) Kang, Y.; Liu, M.; Song, Y.; Huang, X.; Yao, H.; Cai, X.; Zhang, H.; Kang, L.; Liu, X.; Yan, X.; et al. High-resolution ammonia emissions inventories in China from 1980 to 2012. Atmos. Chem. Phys. 2016, 16 (4), 2043-2058.

(57) Zhang, X.; Wu, Y.; Liu, X.; Reis, S.; Jin, J.; Dragosits, U.; Van Damme, M.; Clarisse, L.; Whitburn, S.; Coheur, P.-F.; Gu, B. Ammonia emissions may be substantially underestimated in China. Environ. Sci. Technol. 2017, 51, 12089.

(58) Zhang, F.; Cui, Z.; Fan, M.; Zhang, W.; Chen, X.; Jiang, R. Integrated soil-crop system management: reducing environmental risk while increasing crop productivity and improving nutrient use efficiency in China. Journal of Environmental Quality 2011, 40 (4), 1051-1057.

(59) Zhang, F.; Cui, Z.; Chen, X.; Ju, X.; Shen, J.; Chen, Q.; Liu, X.; Zhang, W.; Mi, G.; Fan, M.; Jiang, R. Integrated nutrient management for food security and environmental quality in China. Adv. Agron. 2012, 116, 1.

(60) Wang, M.; Ma, L.; Strokal, M.; Chu, Y.; Kroeze, C. Exploring nutrient management options to increase nitrogen and phosphorus use efficiencies in food production of China. Agricultural Systems 2018, $163,58-72$.

(61) Ju, X.; Gu, B.; Wu, Y.; Galloway, J. N. Reducing China's fertilizer use by increasing farm size. Global environmental change 2016, 41, 2632.

(62) Erisman, J. W.; Bleeker, A.; Hensen, A.; Vermeulen, A. Agricultural air quality in Europe and the future perspectives. Atmos. Environ. 2008, 42 (14), 3209-3217.

(63) Hou, Y.; Velthof, G. L.; Oenema, O. Mitigation of ammonia, nitrous oxide and methane emissions from manure management chains: a meta - analysis and integrated assessment. Global change biology 2015, 21 (3), 1293-1312.

(64) Meng, Q.; Sun, Q.; Chen, X.; Cui, Z.; Yue, S.; Zhang, F.; Römheld, V. Alternative cropping systems for sustainable water and nitrogen use in the North China Plain. Agric., Ecosyst. Environ. 2012, 146 (1), 93-102.

(65) Qin, W. Exploring Options for Improving Water and Nitrogen Use Efficiency in Crop Production Systems; Wageningen University, 2015.

(66) Wang, L. Situation and Outlook of Feed Utilization in Dairy Industry of China (in Chinese); Chinese Academy Agri. Sci.: Beijing, 2005.

(67) Wang, L. Study on Production Efficiency and Milk Quality in the Main Dairy Areas (in Chinese); Chinese Academy Agri. Sci.: Beijing, 2005.

(68) Strokal, M.; Kroeze, C.; Wang, M.; Ma, L. Reducing future river export of nutrients to coastal waters of China in optimiztic scenarios. Sci. Total Environ. 2017, 579, 517-528.

(69) Velthof, G.; Oudendag, D.; Witzke, H.; Asman, W.; Klimont, Z.; Oenema, O. Integrated assessment of nitrogen losses from agriculture in EU-27 using MITERRA-EUROPE. J. Environ. Qual. 2009, 38 (2), 402-417. 


\section{NOTE ADDED AFTER ASAP PUBLICATION}

This paper published ASAP on April 27, 2018 with incomplete changes to Table 1 due to a production error. The corrected paper reposted to the Web on April 30, 2018. 